\title{
A 19TH CENTURY CLIMATE CHRONOLOGY FOR THE KALAHARI REGION OF CENTRAL SOUTHERN AFRICA DERIVED FROM MISSIONARY CORRESPONDENCE
}

\author{
DAVID J. NASH ${ }^{*}$ and GEORGINA H. ENDFIELD ${ }^{\mathrm{b}, 1}$ \\ ${ }^{a}$ School of the Environment, University of Brighton, Lewes Road, Brighton BN2 4GJ, UK \\ b School of Geography, University of Nottingham, University Park, Nottingham NG7 2RD, UK \\ Received 5 July 2001 \\ Revised 31 October 2001 \\ Accepted 4 November 2001
}

\begin{abstract}
Unpublished materials written by missionaries based at London Missionary Society and Wesleyan Methodist Missionary Society mission stations across the Kalahari region have been used as the primary source for the construction of a historical climatic chronology for central southern Africa for the period 1815-1900. Data from these unpublished documents were supplemented by analyses of published material written by various hunters and explorers (as well as missionaries) who travelled beyond the immediate areas of missionary activity. Key features of the climate chronology are the identification of six drought episodes and seven periods of above-average rainfall which affected various parts of the region. Major dry periods occurred in 1820-27, 1831-35, 1844-51, 1857-65, 1877-86 and 1894-99, of which the droughts in 1844-51, $1857-65,1884-86$ and $1894-99$ were the most widespread. Wetter periods are identified in $1816-17,1829-30,1851-52$, $1863-64,1874-75,1889-91$ and 1899-1900, with the most widely distributed wet conditions occurring in 1889-91. In order to ascertain the reliability of the chronology, the document-derived climate sequence has been compared with available meteorological data for the study area (from Barkly West for the period 1883-1900) and shows good general agreement.

The results of this study have been compared with historical climate chronologies for the former Cape Province of South Africa. This comparison reveals that large areas of the southern African subcontinent experienced dry conditions in $1826-27,1832-35,1848-1851,1858-60,1861-63,1877-81,1884-86$ and 1894-99, with the dry phases of the early 1850s, 1858-60, 1861-63 and 1894-99 possibly extending beyond the northern border of present-day Botswana. Wetter phases affected much of the subcontinent in 1829-30,1851-52, 1863-64, 1874-75, 1889-91 and 1899-1900, with 1874-75 and 1889-91 associated with reports of flooding from central Botswana to the eastern Cape. The causal mechanisms of patterns of climatic variability are unclear, but 19th century drought periods in the Kalahari show a close coincidence with the timing of moderate to strong El Niño-southern oscillation events Copyright (C) 2002 Royal Meteorological Society.
\end{abstract}

KEY WORDS: Kalahari; documentary evidence; climate change; drought; nineteenth century; El Niño

\section{INTRODUCTION}

Patterns of historic climatic variability have been inferred from several sources, of which the most important and reliable are various forms of instrumental meteorological record. Historical records, however, have also been recognized as invaluable proxy sources for the reconstruction of rainfall variations and other climatic changes for periods or locations where meteorological records do not exist. Pioneering studies such as those of Le Roy Ladurie (1971) and Lamb (1982), for example, focused on the reconstruction of global climate changes over the last 1000 years from phenological and other documentary sources. At the continental scale,

* Correspondence to: David J. Nash, School of the Environment, University of Brighton, Lewes Road, Brighton BN2 4GJ, UK; e-mail: d.j.nash@brighton.ac.uk

${ }^{1}$ E-mail: georgina.endfield@nottingham.ac.uk 
Nicholson $(1978,1979,1981,2001)$ has used a wide variety of published and unpublished documentary material to reconstruct climatic chronologies for the Sahel and other areas of Africa for various periods over the past 500 years. Some of the most detailed studies, however, have been at the regional level. For example, Swan, (1981), Metcalfe (1987), O'Hara and Metcalfe (1995) and Endfield and O'Hara (1997) have used a range of historical documentary sources, including maps, unpublished land grant deeds, litigation documents and correspondence between estate owners, to reconstruct changes in rainfall regimes in central Mexico.

Similar techniques have been employed successfully for parts of southern Africa. Nicholson (1981), for example, has inferred that south and south-eastern Botswana were affected by drought in the early 1800 s on the basis of the extrapolation of drought conditions in adjacent areas of South Africa. Furthermore, detailed regional chronologies have been assembled for areas of the former Cape Province of South Africa for the period 1820 to 1900 (Vogel, 1988a,b, 1989; Lindesay and Vogel, 1990), with the impacts of drought episodes upon local populations also assessed (Ballard, 1986). However, our understanding of climate patterns for large areas of southern Africa beyond the borders of present-day South Africa, particularly less densely populated regions such as the Kalahari in the centre of the subcontinent, is less clear. To date, detailed work on 19th century weather patterns in the Kalahari has relied upon hydrological proxies for climate data derived from published sources. These include historical accounts of fluctuations in outflows of the Okavango Delta system, which have been used by Shaw $(1984,1986)$ to identify shifts in the hydrological regime of the Okavango River. Shaw $(1983,1985)$ has also used a similar approach to identify changes in the levels of presently dry lake basins such as the Ngami and Mababe depressions. These studies provide a useful indirect record of climate but cannot be considered representative of rainfall conditions in this part of the Kalahari given that the perennial rivers feeding these systems have their headwaters in wetter areas of Angola and Zambia (Thomas and Shaw, 1991). The only work dealing with climatically direct hydrological proxies in the Kalahari is the study of flows within ephemeral valley systems by Nash (1996). This identifies periods of below- and above-average flow in a number of endoreic and exoreic drainage systems, but is again limited to accounts contained within published sources.

This paper aims to present the first direct evidence for 19th century climate patterns in the Kalahari region of central southern Africa, derived from a range of published, but more importantly, unpublished archival sources. The primary data concerning climatic variability comes from materials written by missionaries working for the London Missionary Society (LMS) and Wesleyan Methodist Missionary Society (WMMS). These include unpublished reports, journals, personal papers and correspondence mostly written from southern Africa to the LMS and WMMS headquarters in London. These sources are supplemented by other published accounts provided by travellers, hunters and traders, as well as missionaries, who crossed the region. This collection of material has been used to construct the first rainfall record for the Kalahari region as a whole for the period 1815 to 1900 . The chronology derived from documentary sources is shown to correlate well with the limited instrumental rainfall data available for this area from the late 19th century. The rainfall record is also viewed within the context of other published chronologies for southern Africa before inferences about the relationship between climate patterns and the occurrence of particular atmospheric phenomena are made.

\section{CLIMATE IN THE KALAHARI REGION}

Prior to discussing the research results in detail, the climate patterns derived from documentary sources should be put in context. Much of southern Africa, and the Kalahari in particular, experiences a predominantly semiarid climate with pronounced seasonality and high interannual variability of rainfall levels. The patterns and causes of climate and climatic variability over southern Africa have been reviewed by a number of authors (e.g. Tyson, 1987; Preston-Whyte and Tyson, 1988; Thomas and Shaw, 1991; Mason and Jury, 1997) and are, therefore, only briefly outlined here. Low rainfall levels can be mainly attributed to the presence of anticyclonic pressure systems associated with the falling limbs of the southern Hadley and Ferrel cells, which create a broad ridge of high pressure centred at around $30^{\circ} \mathrm{S}$ (Tyson et al., 1975). The position of this ridge varies by around $6^{\circ}$ of latitude in association with fluctuations in the position of the inter-tropical convergence zone (ITCZ). The high-pressure ridge is at its most extensive during austral winter months, but is normally 
split into South Atlantic and Indian Ocean anticyclones by the African landmass during the austral summer (Tyson, 1987).

The prevalence of anticyclonic conditions means that much of the southern African interior derives its moisture from air masses moving off the Indian Ocean. As air masses move westward, however, much of their moisture is lost due to orographic effects associated with the highlands of the eastern escarpment. This results in a progressive westward decline in rainfall levels, enhanced in western areas by the arid conditions arising from the presence of the Benguela current off southwest Africa. Mean annual rainfall in Botswana, for example, varies from around $600 \mathrm{~mm}$ in the northeast to below $150 \mathrm{~mm}$ in the arid southwest (Thomas and Shaw, 1991). Major seasonal variations in rainfall occur due to changes in the position of the ITCZ and Congo air boundary (CAB) (McCarthy et al., 2000). During austral winter months, when the ITCZ and $\mathrm{CAB}$ are relatively far north and high-pressure systems are at their best-developed over the southern African interior, rainfall levels in the Kalahari are typically low. However, during summer months when the ITCZ and $\mathrm{CAB}$ move southward, low-pressure systems associated with the CAB may link with thermal lows in central southern Africa to form tropical-temperate troughs. Such troughs are one of the major causes of widespread and intense summer rainfall.

These generalized atmospheric fluctuations produce a distinctly seasonal rainfall pattern with a marked summer wet season and winter dry season, centred around January and July respectively. There is, however, evidence for statistically significant cyclical variability in rainfall (Tyson, 1987). Of greatest significance are 18-20 year and, particularly for this study, 3.5-6 year oscillations in rainfall over the north-eastern part of South Africa, which may, in part, extend into the Kalahari. Periods of wetter or drier conditions are related to changes in the intensity, frequency and persistence of rainfall-producing weather systems, particularly tropical-temperate troughs and their associated cloud bands, which are in turn related to changes in atmospheric circulation in and around southern Africa. Such changes are discussed in detail by Mason and Jury (1997) and are considered to be the result of the interaction of a number of mechanisms. The 18-20 year cycle may be attributed to an 18 year oscillation in the luni-solar tide (Currie, 1993), which could trigger similar cycles in sea-surface temperatures. It has also been suggested that cyclical changes are caused by variations in atmospheric standing wave 1, which may produce a 20 year cycle in sea-surface temperatures over the eastern equatorial Pacific (Hurrell and van Loon, 1994). The 3.5-6 year cycle is closely linked to inter-hemispheric teleconnections associated with the southern oscillation (SO). Climatic variability occurs during SO events due to convergence zones in sub-equatorial southern Africa shifting either eastwards (during low phase/warm/El Niño events) or westwards (during high phase/cold/La Niña events). This results in changes in the paths of moisture-bearing air masses that produce drought conditions (during low-phase events) or higher rainfall (high-phase events) in southern Africa (Tyson, 1987; Mason and Jury, 1997). These relationships are discussed further in Section 6.2.

\section{DATA SOURCES}

Unlike more southerly parts of the southern African subcontinent, very few accounts of the landscape and climate of the Kalahari exist prior to the 19th century, except from those provided by oral histories (Nash, 1996). From the early 1800s, however, written reports containing observations of climate and environment become more widely available as hunters, explorers and, more importantly, missionaries began to travel extensively across the Kalahari region. These written accounts provide the key sources of historical data for the interior of the subcontinent in the almost complete absence of more conventional written information sources such as newspapers, which only appear in the lattermost part of the century.

The primary data sources used within this study were unpublished materials written by missionaries working for the LMS and WMMS at 20 mission stations and associated out-stations established within and adjacent to the Kalahari region during the 19th century (Figure 1). The earliest mission station was founded at Lattakoo (later known as Kuruman) in 1816 (Lovett, 1899), followed by further important stations at Mabotsa (1843), Kolobeng (1846), Shoshong (1862), Molepolole (1866), Taung (1868), Palapye (1869), Kanye (1871) and Barkly West (1876). Missionaries were in regular written contact with colleagues at other mission stations 


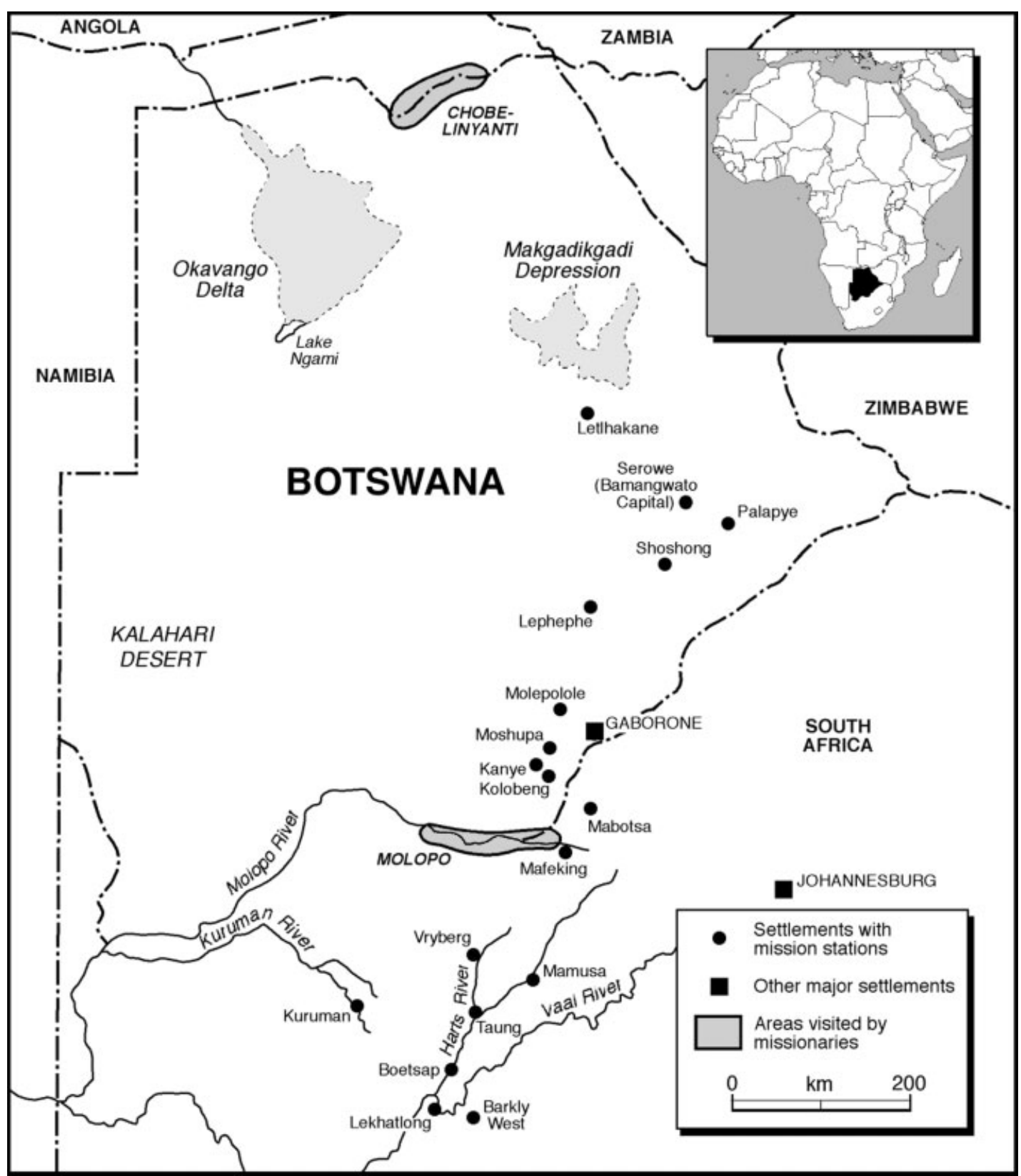

Figure 1. The location of key mission stations in and around the Kalahari region, together with areas frequently visited or crossed by missionaries

within the region and other parts of southern Africa, as well as with LMS and WMMS headquarters in London. Whilst primarily concerned with evangelical work and current affairs, most letters, reports and journals are also a rich source of information about the local and regional environment and, more significantly, climatic conditions (Endfield and Nash, in press). This written correspondence is of particular value, as it is usually accurately dated and place-specific, although it should be noted that some letters containing, for example, annual reports, often allude to broader circumstances over longer time periods. More importantly, many missionaries were based in southern Africa for periods of many years and can, therefore, be considered to be in a good position to document perceived climatic variability. 
The majority of surviving materials sent from and between mission stations are now held at the Council for World Mission (CWM) archive, School of Oriental and African Studies, University of London, as well as at various archives in South Africa. The most important of these materials is a collection of over 1850 items of personal correspondence from LMS and WMMS missionaries in the Kalahari region. ${ }^{1}$ The number of items of correspondence per year is small for the early part of the study period (Figure 2), but these increase rapidly after the 1850s when missionary work and exploration expanded. The archive also includes copies of annual reports from all LMS mission stations, personal journals kept by missionaries based at these stations, and collections of personal papers by key LMS missionaries, including David Livingstone, Robert Moffat, Holloway Helmore and John MacKenzie. These materials were especially important for the period prior to 1850 , when the number of available letters from which to identify climatic data was relatively limited. Annual reports, where available, provide key yearly summary data for mission stations, whilst journals and personal papers incorporate continuous records of missionary activities and observations.

In addition to this range of unpublished sources, further primary data were identified within published sources, including books and travelogues written by 19th century hunters, traders and missionaries travelling throughout the region. These data sources were of particular importance for the first half of the 19th century when missionary work, and as a result correspondence, was limited to the northern parts of present-day South Africa. Key references ${ }^{2}$ were identified from bibliographies such as Morton (1994) and Shaw and Nash (1998).

\section{METHOD OF ANALYSIS}

Each of the archival and, wherever possible, published sources were read in chronological order, with any climate and other environmental information recorded verbatim. Three categories of climate data were identified across the range of data sources: (i) details of catastrophic or unusual events, such as major droughts, dry periods, storms, floods and unseasonable frosts; (ii) general anecdotal comments about the weather, including observations of early or late arrival of the rainy season; and (iii) indirect evidence of climatic variability, such as harvest loss and changes in river regime. The first two of

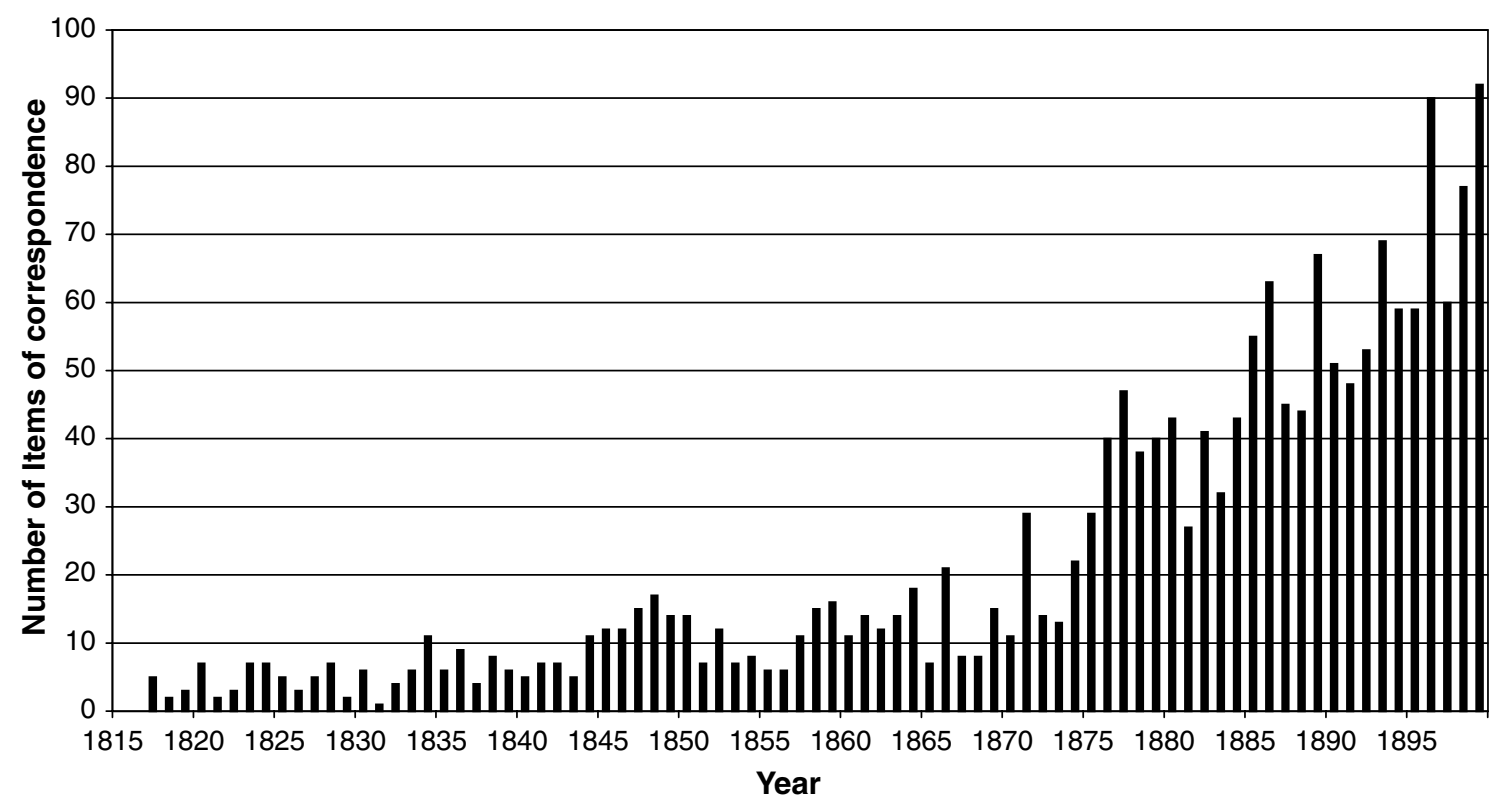

Figure 2. Number of letters per annum available from central southern African mission stations in the CWM archives for the period 1815-1900 
these categories of data were considered most reliable, as harvest loss is often attributable to socioeconomic factors other than below-average rainfall (unless supported by climatic information), and changes in river flow may be due to environmental variability in headwater regions beyond the study area.

Information from each of the data sources was compiled on an annual basis for each of the 20 mission stations, plus areas such the Molopo and Chobe-Linyanti rivers, which were frequently crossed by travellers. Data for each location were analysed by 'rain-year' (July to June, encompassing the Kalahari austral summer wet season) to identify and corroborate evidence, and subsequently grouped into one of five categories based upon the predominant climatic conditions reported during the year: very wet/floods; relatively wet; normal (seasonal rains); relatively dry; and very dry/drought. These categories were chosen to be directly comparable with other published work on southern African climate history (e.g. Vogel, 1988a,b, 1989; Lindesay and Vogel, 1990). Attempting such a climate classification is fraught with difficulties. For example, relative amounts of rainfall in any given year will vary according to the opinion of the observer, as well as from place to place. To overcome potential differences between reporters, classifications for any given place in a particular rain-year were, ideally, based upon anecdotal evidence from more than one observer. Potential errors due to the spatial variations in average rainfall level across the Kalahari region discussed above were overcome by, wherever possible, basing the classification upon observations made by missionaries who had been resident at a location for some time. Rainfall levels can also be affected by topography, although in the relatively flat interior of the Kalahari such orographic influences are considered unlikely and were discounted. Only clearly extreme events were classified into the very wet and very dry categories, with other observations falling into the three milder categories based upon the weight of documentary evidence. Normal years were only identified where observers made little or no reference to 'abnormal' rainfall conditions or where correspondents commented that rainfall had been unremarkable. Examples of the types of documentary evidence used to place data from a given location into a particular climatic category are shown in Table I, with the overall results of the classification shown by rain-year in Figure 3.

In order to ascertain the reliability of the climate chronology presented in this study, results were compared with available meteorological records. Instrumental weather data are available for parts of South Africa from 1841 onwards (Tyson, 1987), but the earliest reliable records for the study area only begin in 1883 at Barkly West. The documentary-derived climate chronology for Barkly West mission station was therefore compared with the deviation in measured rainfall level from the 1883-1900 mean annual rainfall (Table II). The mean annual rainfall figure was calculated according to rain-year from monthly instrumental records to allow direct comparison between the two data sets. This comparison demonstrates broad agreement between the documentary-derived record and measured rainfall data, suggesting that the climate record reported within this study is likely to be relatively reliable. However, it also highlights the tentative and inherently generalized nature of any documentary-derived chronology of this type. For example, the 1889-90 rain-year was classified as 'normal' but experienced relatively late heavy rains, whereas the 1893-94 rain-year was also 'normal' but incorporated a spring drought followed by heavy rainfall in January 1894. Meteorological data are also available for Vryburg (1886-1900), Taung (1898-1900) and Mafikeng (1898-1900), but either incomplete instrumental or documentary-derived records from these locations preclude meaningful comparison.

\section{RESULTS}

The overall results of this research yield an almost continuous record of climate data for the Kalahari from 1815 to 1900 , by which time LMS and WMMS missionary work in the area had almost ended. Data are mostly restricted to northern South Africa until the 1850 s, when mission work expanded into present-day Botswana (Lovett, 1899), but reveal at least six significant drought episodes and seven major wet periods or floods affecting various parts of the region. Evidence for the distribution and nature of these major episodes will now be described. It should, however, be noted that the apparent spatial extent of drought- or 
Table I. Examples of statements from documentary data used in the fivefold classification of climate by rain-year

\begin{tabular}{|c|c|}
\hline Classification & Illustrative quote \\
\hline Very wet/floods & $\begin{array}{l}\text { 'At present I am plainly told that the state of the country forbids my } \\
\text { attempting the journey. Rivers are flooded. Roads are swampy. Wagons } \\
\text { have been stuck for many weeks... The rains comes in through the } \\
\text { walls and roof. . In a heavy rain, my papers and books are constantly } \\
\text { destroyed.' (LMS C 48-1-A, Hepburn, Palapye, } 22 \text { January 1891) }\end{array}$ \\
\hline Relatively wet & $\begin{array}{l}\text { 'We have had unusual rains again this year and the dampness of a } \\
\text { mud-floor house, leaking in every direction has given Mrs Brown } \\
\text { another severe and long-continued cold...' (LMS C 38-1-A, Brown, } \\
\text { Taung, } 29 \text { March 1875) }\end{array}$ \\
\hline Normal & $\begin{array}{l}\text { 'The country is reported quiet everywhere at present. Splendid rains } \\
\text { have fallen and the people are ploughing as fast as possible.' (LMS C } \\
41-3-D \text {, Wookey, Barkly, } 8 \text { December 1888) }\end{array}$ \\
\hline Relatively dry & $\begin{array}{l}\text { 'We have no rain - one good shower alone this year while all around } \\
\text { us the rains have been abundant. The Kolobeng gets smaller and smaller } \\
\text { but has not run in to the water course for the last three weeks.' (LMS } \\
\text { DL Box 5, Kolobeng, November 1848) }\end{array}$ \\
\hline Very dry/drought & $\begin{array}{l}\text { 'We have been visited by drought here for about } 6 \text { years and this year } \\
\text { we have had only one good rain in twelve months. Oh, what famine, } \\
\text { death and desolation reigns among the poor inhabitants among whom } \\
\text { we dwell which we must behold from day to day, without being able to } \\
\text { help them...' (LMS C 9-4-B, Hamilton, Lattakoo, } 15 \text { December 1825) }\end{array}$ \\
\hline
\end{tabular}

flood-affected areas may be as much a product of data availability as a true reflection of regional climatic conditions.

\subsection{Occurrence of major droughts and relatively dry periods}

From the documentary record, major droughts of varying severity appear to have affected central southern Africa over the periods $1820-27,1831-35,1844-51,1857-65,1877-86$ and 1894-99. Of these, drought phases during 1844-51, 1857-65, 1884-86 and 1894-99 were the most widespread, affecting areas as far apart as Barkly West in South Africa and Lake Ngami and the vicinity of present-day Serowe in Botswana.

The first major dry phases apparent within the period of record affected the Kuruman region between 1820 and 1827 and again between 1831 and 1835. Many of the early accounts of the climate and environment around Kuruman stress the generally dry nature of the country, largely based on comparisons with conditions experienced in more temperate countries. However, the 1820 s drought clearly represented significantly drier conditions than had been experienced since the establishment of the mission station in early 1816. Drought conditions began following low levels of spring rainfall towards the end of 1820 and continued until the onset of late rains in early 1827 . The prolonged nature and severity of the 1820 s drought is indicated by commentary from a number of missionaries and can be illustrated by the quote from $\mathrm{Mr}$ Hamilton included within Table I. This drought also appears to have been much more widespread across southern Africa, particularly in the early- to mid-1820s, as suggested in a letter from Mr Hamilton describing a journey from Cape Town to Kuruman:

... the oxen had suffered much at and in the vicinity of Cape Town with rain, and on this side of the colony with drought from Beauford [Beaufort West] to the Great River...

LMS C 9-1-B, Hamilton, New Lattakoo, 17 February 1823 


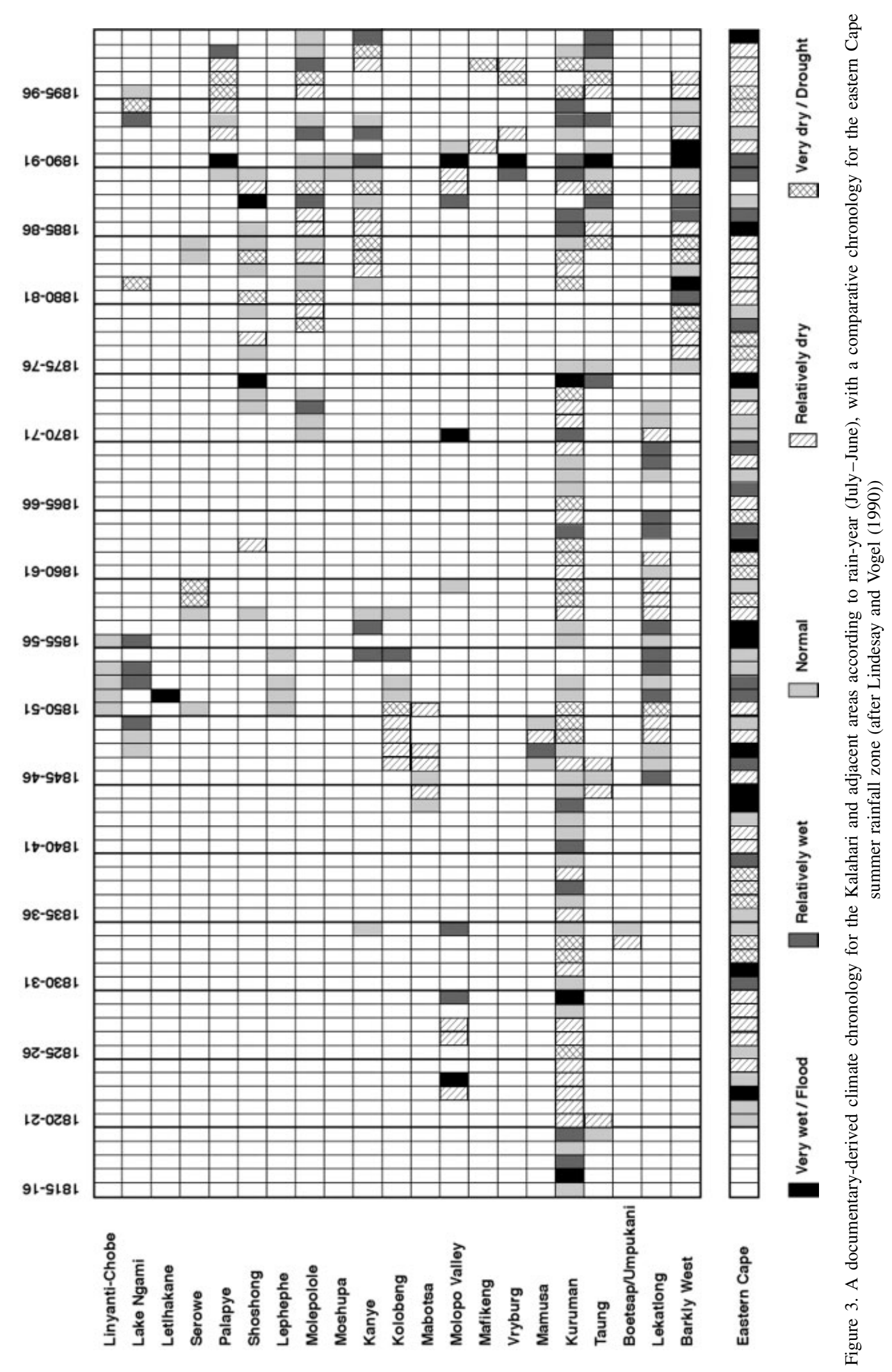


Table II. Comparison of documentary-derived climate classification with rainfall records for Barkly West (1883-1900). Rainfall deviation is calculated for each July-June rain-year by comparison with the $531 \mathrm{~mm}$ mean rainfall figure for the 17 year period. Missing or incomplete meteorological data for a year is indicated by an asterisk. A negative sign indicates rainfall below the calculated mean value

\begin{tabular}{lcc}
\hline Season (July-June) & $\begin{array}{c}\text { Rainfall deviation from } \\
\text { 1883-1900 mean }(\mathrm{mm})\end{array}$ & $\begin{array}{c}\text { Climate classification } \\
\text { derived for rain-year }\end{array}$ \\
\hline $1883-84$ & $*$ & Very dry/drought \\
$1884-85$ & -300.2 & Very dry/drought \\
$1885-86$ & $*$ & Relatively dry \\
$1886-87$ & 18.6 & Relatively wet \\
$1887-88$ & 149.9 & Relatively wet \\
$1888-89$ & -223.6 & Relatively dry \\
$1889-90$ & 159.1 & Normal \\
$1890-91$ & 292.1 & Very wet/floods \\
$1891-92$ & $*$ & Very wet/floods \\
$1892-93$ & -132.5 & Relatively dry \\
$1893-94$ & 173.9 & Normal \\
$1894-95$ & 58.4 & Normal \\
$1895-96$ & $*$ & Relatively dry \\
$1896-97$ & $*$ & Relatively dry \\
$1897-98$ & -64.1 & No data \\
$1898-99$ & -98.7 & No data \\
$1899-00$ & -32.6 & No data \\
\hline
\end{tabular}

The drought of 1831-35 was of shorter duration but appears to have been no less severe. Robert Moffat, for example, notes in a letter written from Kuruman in 1834:

The drought of this season has been excessive. Almost one perpetual blaze of solar fires ever since the commencement of summer, and of course never before experienced so much heat. The wind sometimes felt like flame and the earth seemed ignominious...

LMS C 14-2-F, Moffat, Kuruman, 3 February 1834

The regional extent of dry conditions is, however, unclear owing to a lack of correspondence from regions beyond Kuruman mission station.

The first major widespread drought for which there is direct evidence from documentary sources occurred between late 1844 and 1851. This began as a sequence of relatively dry years affecting locations as far apart as Lekatlong, Taung and Kolobeng (Table III), before becoming particularly severe from the late 1840s onwards. The drought does not appear to have been exclusively a product of low rainfall, but, according to missionary accounts, may have occurred as a result of the late arrival of the rainy season in combination with relatively low levels of precipitation. For example, Mr Edwards notes from Mabotsa:

Since our residence here we have been subject to reproach on account of the absence of rain, when the interests or wishes of the natives were not realised. Last season the rains were rather late and suspicion fell upon us as the cause LMS C 23-1-B, Edwards, Mabotsa, 6 August 1847

Despite its duration, the drought was not continuous across the entire region, and it was briefly alleviated by a period of relatively heavy rainfall in the early part of the 1847-48 rainy season, which affected the areas around the mission stations at Mamusa and Mabotsa. Relatively wet conditions appear to have occurred throughout the 1847-48 rainy season in Mamusa, whilst the heavy rains at Mabotsa merely punctuated an otherwise relatively dry year. As Mr Edwards records: 
Table III. Selected quotes illustrating the regional extent and severity of the 1843-51 drought

\begin{abstract}
'... there has been since October a want of rain on the station, especially during the last months - there are thunderstorms frequently round about but merely light showers here - the heat is very oppressive. Thermometer not seldom less than at 100 in the shade' (LMS C 21-1-A, Edwards, Mabotsa, 28 January 1845)

'The year that has just closed has been one of anxiety and care; we have been anxious as to the temporal welfare of the people; their crops having failed through drought... we fear as to the result of the coming year as the drought is still severe...' (LMS C 22-1-B; Hamilton et al., Kuruman, 18 November 1846)

'The season is one of great drought in the end I fear will be one of suffering. It is so general that we have complaints from all quarters. Here we have been helped with a few showers but with very few exceptions the whole country from the borders of the Colony to the Bakwena country is burnt up with intense heat...' (LMS C 24-1-A, Moffat, Kuruman, 24 January 1849)

'We have had an intensely hot and dry season. Only five inches of rain have fallen during the year and the thermometer has managed higher than we have ever seen it. The Kolobeng is nearly dry...' (LMS DL Box 3, Kolobeng, 26 May 1849)

'It will be observed that my late letters have been written under considerable depression of spirit owing to the low state to which the station has been induced by a series of droughts...' (LMS C 26-1-A, Helmore, Lekatlong, 9 April 1851)

'To these unfavourable circumstances were superadded a series of remarkably dry years - the last 1850-51 exceeding all the preceding in extent of country over which drought prevailed...' (LMS Livingstone's Bechuana Journal, April/May 1851)
\end{abstract}

Very abundant rains having already fallen, our circumstances in temporals are much more agreeable than at this season of 1846 when a general drought prevailed for which we were blamed, cursed and reproached in no moderate terms

LMS C 23-1-B, Edwards, Mabotsa, 29 October 1847

There is also evidence to suggest that this drought may have been considerably more widespread and extended well beyond the area of study. For example, David Livingstone describes conditions in the Boteti River, the main outflow of the Okavango Delta system which links the delta swamps to the Makgadikgadi depression:

The River Zouga [Boteti] has not risen to within three feet of what it did last year — drought seems to have prevailed at its sources

LMS Livingstone's Bechuana Journal, 27 August 1851

Given that the Okavango system rises in the highlands of Angola, it is possible that drought conditions were much more widely distributed across central southern Africa towards the end of the 1844-51 dry phase.

Widespread and severe drought also occurred in various parts of the region between 1857 and 1865, punctuated by an exceptionally wet spell that affected the areas around Kuruman and Lekatlong in 1863-64 (discussed below). Unlike the 1844-51 dry period, this drought phase started relatively rapidly following spatially variable and unreliable rainfall in the 1857-58 rainy season. As Mr Ashton notes from Kuruman:

Last year the rains fell too late and the mature corn came to nothing except in a few places such as where there is irrigation. And even in this station we had severe frost very late in spring which destroyed a great part of what the irrigation had produced... This is now the third month of spring and not a drop of rain has fallen!

LMS C 31-1-B, Ashton, Kuruman, 10 October 1858

Despite references to occasional summer thunderstorms, it would appear that rainfall levels were significantly below average across large parts of the region and further south into the Cape Province of South 
Africa (Table IV). The lack of moisture not only appears to have affected farming, it also considerably hampered communication between mission stations. As a result, drought conditions are frequently referred to in correspondence.

A further two prolonged drought periods affected central southern Africa towards the end of the 19th century, in 1877-86 and 1894-99. The 1877-86 dry period contains two widespread dry phases (1877-81 and 1884-86) that can be recognized across the entire region from northern Botswana to Barkly West, separated by a period of more variable conditions. The first of the dry phases appears to have been most severe and damaging to local populations, coming at the end of a sequence of years with slightly below average rainfall and also being coupled with regional war. For instance, Mr Ashton reports from Barkly West:

... provisions in this country are almost at famine prices, no consequence of the long, continued drought and on account of the war which has been raging around us. We depend mostly for provisions on the Transvaal district, which is still involved in war, there is every probability that Natal will soon be in the same position...

LMS C 39-3-D, Ashton, Barkly West, 31 December 1878

The end of the 1877-81 dry phase does not appear to have been synchronous across the region, with, for example, Mr Hepburn in Shoshong suggesting in February 1880 after a period of prolonged drought that 'there has never been such a year known as this' for rain (Hepburn, 1895: 171) whilst other areas continued to experience low rainfall. The two drought phases of $1877-81$ and $1884-86$ were separated by a 3 year period in which climatic conditions also appear to have been highly spatially variable. For example, floods are reported on the Vaal River in early 1882 by Mr Ashton in Barkly West (LMS C 41-3-A, Ashton, Barkly West, 21 February 1882) at the same time as drought conditions are continuing in the same area (LMS C 41-3-A, Ashton, Barkly West, 1 March 1882). Also in 1882, drought is reported from Kuruman and Lake Ngami at the same time as relatively normal rainfall levels are occurring in the areas around Kanye and Molopolole. However, 1884-86 represented a return to widespread drought conditions, as reported by Mr Ashton at Barkly West.

You will be sorry to hear that after a succession of dry seasons, this is the driest we have had for a very long time LMS C 44-2-C, Ashton, Barkly West, 13 November 1886

Table IV. Selected quotes illustrating the regional extent and severity of the 1857-65 drought

'Our farming hitherto has been anything but an agreeable one, for the season being one of unprecedented drought from the entrance of the Karoo to this place' (LMS C 31-1-B, Moffat, Kuruman, 1 December 1858)

'At present there is scarcely any intercourse with the Interior owing to the extreme drought which has prevailed during nearly the whole of the last year. The distance from one water to another is in some places so great - 60 or 80 miles, besides heavy roads, that travelling is attended with great risks, and not unfrequently much loss... the drought referred to, and which still continues, together with the blight of last year's crop of maize, on ground irrigated, has been followed by the natural consequence of hunger, which has been, and is still felt from the Bakwena to this place' (LMS C 32-1-A, Moffat, Kuruman, 5 November 1860)

'The past season has been one of severe and universal drought, and consequently intensely hot. Food of every description as well as that obtained from the wild, exceedingly scarce, and the latter, from its unwholesome nature, sometimes causes disease and death. Near the sea coast on the south to the Zambesi, fountains, streams and pools have been dried up where anything like scarcity of water was never heard of. Cattle of all descriptions died everywhere from sheer poverty, and the losses of draught oxen to travellers, hunters and traders have been very severe' (Moffat, Kuruman, 1861, reported in London Missionary Society (1862): 14) 
This dry period appears to have ended in December 1886, with widespread and continuous rainfall reported from Barkly to Molepolole.

The final dry phase apparent from documentary evidence occurred between 1894 and 1899 . This affected almost all of the mission stations within the area of study and was also amongst the most severe droughts of the century (Table V). The onset of extremely dry conditions in late 1894 followed a very wet rainy season in 1893-94 and was ended by the unusually wet summer of 1899-1900 (described below). The drought was especially damaging for local populations as it coincided with an outbreak of rinderpest, which severely depleted cattle stocks across the region. Some rainfall did occur during this dry period, but it was frequently either relatively late or of insufficient volume. Mr Ashton notes from Barkly West:

Severe drought and locusts... in the past year... the rains this season have been so late that there was not time to plough

LMS R Box 2, Ashton, Barkly West, 28 December 1896

Drought conditions do not appear to have been restricted to the Kalahari; they also extended further south. The widespread nature of the drought was documented by Mr Brown in a letter in 1895 describing a journey from Kimberley to Kuruman:

Our journey hitherwards was the worst we had ever experienced. Owing to the great drought, the road was very dusty... No rain has fallen yet this season. I cannot possibly go visit my parish till the rain does come. I hope it will not be long in coming. The natives are already without food and food is both scarce and dear at the traders. There are still seven months to harvest, but if we get no rain there will be no harvest

LMS C 52-2-B, Brown, Kuruman, 15 October 1895

This would suggest a drought affecting much of the southern African summer rainfall zone from northern Botswana into Cape Province.

Table V. Selected quotes illustrating the extent and severity of the 1894-99 drought

'Last year, the drought was so severe that there was very little ploughing to be done and consequently there was and is still a great scarcity of food among the people. And now this year also we have been six months without rain; we have had a few showers but not sufficient to enable the natives in the district to plough and the season is now coming to an end' (LMS C 52-2-C, Ashton, Barkly, 5 December 1895)

'Here as in other parts of the district the drought has been great, the crops are withered for want of rain, starvation is staring people in the face; already they are subsisting on berries, roots and insects' (LMS C 53-1-B, Brown, Kuruman, 27 February 1896)

'The drought is not yet broken up either in the north or here and present surroundings and future prospects are depressing in the extreme' (LMS C 53-3-C, Brown, Taung, 10 November 1896)

'You will be very sorry to hear the bad news from this part of south Africa. The crops have again failed making the third year in succession. The end of this month brings the rainy season back to a close yet at present we have had no rains worth speaking of' (LMS C 54-1-B, Williams, Molepolole, 10 March 1897)

'You know how long I have been here at Kanye + have never seen any such dryness. So far as I can learn in the southern part of Bechuanaland, all hope of a harvest is pretty well at an end except for a few who have fountains with which to irrigate their lands' (LMS Report Box 3, Price, Kuruman, 6 January 1898)

'The long drought of last season too has seriously affected (together with the locusts) the year's crop' (WMMS South Africa Correspondence Fiche Box 27, Fiche 1067, Transvaal 1891, Box 330, Rogers, Mafeking, 19 May 1898) 


\subsection{Occurrence of floods and relatively wet periods}

In addition to the dry periods described above, notable wet phases can be identified in 1816-17, 1829-30, 1851-52, 1863-64, 1874-75, 1889-91 and 1899-1900 which affected various parts of the Kalahari. The most widespread wet conditions occurred during 1889-91, with severe storms and floods affecting mission stations across the whole region, as well as other parts of South Africa. In general, wet phases appear to be of much shorter duration than dry phases, and, as might be expected in a region with a semi-arid climate, are more spatially variable.

The earliest apparent wet phase identified from documentary sources occurred in the vicinity of Kuruman in late 1816 and early 1817. Despite the fact that missionaries had not been in the area very long and could, therefore, be considered to be in a poor position to judge volumes of rain, they were able to draw on local knowledge regarding the levels of rainfall. For example, Mr Read notes in late 1817:

... the wagons... had not been able to cross the Craddock River on account of it being fuller than ever known and have not returned yet

LMS C 7-2-D, Read, New Lattakoo, 5 September 1817

Many of the rivers in the vicinity of Kuruman are either spring fed or have local sources, suggesting relatively heavy rain in the local area earlier in the year. This is supported by statements in an earlier letter by Read:

The rain fell very late last year as mentioned in my last... since that time we have had constant rains and many say we brought the helping with us...

LMS C 7-1-C, Read, Lattakoo, 15 March 1817

Widespread heavy rainfall occurred in southern parts of the study area in 1829-30 and across the whole region in 1851-52. The first of these wet periods affected the area between Kuruman and the Molopo River. Abnormally early rainfall started during the winter of 1829, which was described by missionaries as 'a remarkable winter for rains' (LMS C 11-3-D, Moffat and Hamilton, Kuruman, 12 August 1829). Wet conditions continued into the summer of 1829-30, with heavy rainfall also reported by Moffat in the vicinity of the Limpopo and Crocodile rivers to the east of the region (Wallis, 1945: 11-13). Above-normal rainfall in 1851-52 is documented from the Middle Kalahari and at Lekatlong in the south. For example, David Livingstone describes 3 days of heavy rain in the vicinity of the presently dry Letlhakane valley, which drains into the Makgadikgadi depression, that made the valley '.. assume the appearance of a large river flowing northwards' (LMS Livingstone's Bechuana Journal, Letlhakane, September 1851). Most mission stations describe what appear to be normal conditions at this time, but Livingstone records a meeting with Mr J. McCabe in 1852 who reported evidence for good rains across the entire country when returning from Lake Ngami to Kolobeng (Livingstone, 1857: 121-122).

A wet period in the summer of 1863-64, punctuating the 1857-65 drought, appears to have mostly affected southern parts of the region, as it is not reported in correspondence from any of the more northerly mission stations. Large amounts of rainfall occurred in the areas around Kuruman and Lekatlong missions, leading Robert Moffat to report that:

We have had a remarkable rainy season such as I never before witnessed in the country LMS C 33-3-A, Moffat, Kuruman, 9 March 1864

The period of heavy rainfall continued into late 1864 and caused considerable disruption of communication between mission stations on account of high river water levels. The wet phase of 1874-75 was much more widespread, affecting areas as far apart as Shoshong and Taung. Heavy late rains caused extensive flooding both within the study area and across large parts of South Africa. Mr Ashton notes in a letter written from Kuruman:

All the bridges in the road from here to the Bay [Algoa] have just been smashed away which will add much to the inconvenience of travellers, cause detentions and, of course, add to the expense. Mr Helm, who is expected here 
tomorrow writes from Hope Town to say that he has had great difficulties in consequence of bad roads through the recent floods....

LMS C 38-1-A, Ashton, Kuruman, 19 January 1875

By far the most significant wet phase to affect the Kalahari region occurred from 1889 to 1891 . The rainy season of 1889-90 appears to have been relatively wet in a number of the more southerly mission stations in the region, including Vryburg and Kuruman, with other areas experiencing relatively normal rainfall levels. The exact degree to which rainfall was above average is uncertain, as this season followed closely after a drought period and accounts of rainfall amounts may, as a result, be slightly exaggerated. However, the following summer of 1890-91 was abnormally wet. Storms and floods are recorded in areas as far apart as Palapye and Barkly West, with adversely wet conditions reported for all mission stations apart from Molepolole and Moshupa (Table VI). Rainfall appears to have been particularly heavy in southern parts of the Kalahari, with severe disruption to communications. Heavy rainfall also seems to have occurred over a much larger area of southern Africa. For example, Bryden describes difficulties experienced during a journey to Vryburg from Cape Town in early 1891 :

Tremendous rains had been falling for some weeks up-country, and, after waiting for several days in the hope of hearing that the Vaal River temporary bridge, which had become flooded, was passable by rail, and that the Harts River bridge, which had been swept away, was repaired, I set off on the $26^{\text {th }}$ January for Vryburg. The Orange River, as we crossed it, was swollen and muddy, but after passing Kimberley and reaching the Vaal we found the temporary bridge still twelve feet under water...

Bryden (1893): 453

Table VI. Selected quotes illustrating the extent of the heavy rainfall and floods of 1889-91

'The drought is now broken up; since the 4th January, splendid rains have fallen.' (LMS C 46-1-A, Lloyd, Shoshong, 13 January 1889)

'There had been heavy summer rains for some days, during which Vryburg had become a quagmire, and the inhabitants waded forlornly about, as is their custom, in "field" boots, top boots, macintoshes, and any other gear calculated to withstand the swamps, holes and "sluits", that everywhere abounded' (Bryden (1893): 19, referring to 6 February 1890)

'We have had a great deal of rain and the country here is splendid just now' (LMS C 47-1-B, Wookey, Kuruman, 11 March 1890)

'At present I am plainly told that the state of the country forbids my attempting the journey. Rivers are flooded. Roads are swampy. Wagons have been stuck for many weeks...' (LMS C 48-1-A, Hepburn, Palapye, 22 January 1891)

'At the end of 1890 and beginning of 1891 again, when the rains returned, they were prodigious and both the rivers [the Maritsane and Setlagole tributaries to the Molopo] ran strongly for weeks together, so strongly, indeed, that my successor at the Junction, Mr. P. Gethin, had occasionally to swim the torrent just below the huts in order to receive his mails...' (Bryden (1893): 24-25)

'Heathens who have lived in the country for many years say they have never known a season to be as this one. We had feared another year of drought and famine, but our prayers for rain have been abundantly answered' (LMS C 48-1-C, Price, Kuruman, 18 April 1891)

'During the summer of 1890-91 the rains were enormous, and gave a total of not less than 50 inches [at Vryburg]. This was, of course, an abnormal season, the natives stating that such rains had not happened within their memory. At Vryburg from October 1891 to April 1892 the rainfall was 27.24 inches which means a fair average season' (Bryden (1893): 115) 
whilst Mr Ashton in Barkly West also notes:

I regret that I have to inform you that it is quite impracticable for us to hold a committee meeting in May for the Harts River is still impassable, overflowing its banks to a great extent...

LMS C 48-1-C, Ashton, Barkly West, 16 April 1891

Heavy, but less damaging, rainfall appears to have occurred during 1899-1900, following on immediately from one of the worse drought episodes of the 19th century (as noted above). Above-normal rainfall is reported from Kuruman to Palapye, and appears also to have been widespread over large areas of South Africa. Mr Price, for instance, reports on a journey to Kuruman from Cape Town:

As we passed up the country and especially after we crossed the Orange River we were freshly cheered to find that there had been a good rain everywhere. The country is simply lovely

LMS C 56-1-C, Price, Kuruman, 9 May 1899

In addition to the more widespread wet conditions mentioned above, there are also other accounts of isolated flood events that suggest localized above-average rainfall. The earliest of these is from the spring-fed, but presently dry, Molopo valley (Nash, 1996) which is described at Pitsane by Robert Moffat in a letter written on 29 July 1824:

The town [Pitsane] lies about twenty minutes walk from the Molopo River, which at present runs with a tolerable stream but for the most part of the year is dry

Schapera, (1951): 120

As Pitsane is over $100 \mathrm{~km}$ from the source of the Molopo, this suggests relatively heavy rainfall over the headwater regions during the 1823-24 rainy season. Localized heavy rain in the vicinity of Kuruman is also reported in early 1894. As Mr Price notes:

... the road between the [mission] station and the fountain was quite impassable for weeks - that has dried up - and now a very considerable river is pouring into the valley-between this and Wellmore's Dam from the Old Hope Town Road. Streams flow from fountains at distances of from three to twenty miles from the river and it is not likely to dry up for months - the sand road is utterly impassable. The Kuruman River runs in an unbroken stream into the Orange River and therefore to the sea, so that there is now water communication between Kuruman and London...

LMS C 51-1-C, Price, Kuruman, 27 May 1894

\section{DISCUSSION}

\subsection{Comparison of the 19th century climate chronology for the Kalahari with documentary-derived chronologies for former Cape Province, South Africa}

The historical climatic chronology reported in this paper can be directly compared with other detailed accounts of 19th century weather patterns in the southern African summer rainfall zone, such as those compiled for the former Cape Province of South Africa by Vogel (1988a,b, 1989). These studies (summarized on Figure 3) reveal periods of below-normal rainfall in the eastern Cape in the late 1820s, 1833-38, early 1840s, 1846, 1849, 1851, late 1850s, early 1860s, 1865-66, 1869, 1872-73, late 1870s, 1881-85, 1892 and 1894-99. Of these dry episodes, those in 1833-34, 1837-38, 1859-62, 1877-78 and 1895-96 are considered to represent extremely severe droughts (Lindesay and Vogel, 1990). Periods of above-normal rainfall occurred in 1823, the early 1830s, 1844-45, 1847-48, 1852-57, 1863-64, 1867-72, 1874-75, 1886-91 and 1900 (Vogel, 1989). Rainfall patterns for the southern Cape summer rainfall zone show slight differences to those of the eastern Cape (Vogel, 1988a), but drier conditions appear to have occurred across much of the province in the years $1825-29,1849-51,1872-78$ and 1881-96 whilst wetter conditions were prevalent in 1830-33, $1844-48$ and $1852-60$. 
Phases of drought identified for various parts of the Kalahari and surrounding regions show good general agreement with periods of drier climate in the eastern Cape summer rainfall zone. As noted above, drought affected central southern Africa in 1820-27 and was especially severe in 1826-27, when much of the eastern Cape summer rainfall zone was also experiencing extreme dry conditions. The same is true of the 1831-35 drought, which was at its most intense in 1832-35, although the extent to which excessively dry conditions extended north of Kuruman during this period is unclear owing to a lack of data availability. The dry period identified during 1844-51 (and especially 1848-51) coincides with widespread drought across South Africa, suggesting that much of the subcontinent was experiencing low rainfall availability at that time. Drought may have extended as far north as central Angola, as low water levels are reported in outflows of the Okavango river system in the early 1850s. Dry conditions in 1857-65 (which were at their most intense in 1858-60, 1861-63 and 1865-66), 1877-86 and 1894-99 also correlate well with periods of below-average rainfall at a subcontinental scale. The drought that affected large areas of South Africa in the summer of 1861-62 is reported by Vogel (1989) to be one of the most widespread and severe of the 19th century, and this extreme drought, on the basis of documentary evidence, extended well into the southern Kalahari. The 1894-99 drought phase, which appears to have been the most severe in the Kalahari region during the period of study, also seems to have been widespread across large areas of the eastern Cape.

The distribution of wet phases in the Kalahari is also directly comparable with records for Cape Province, although it can be noted that the study area, in general, appears to have experienced fewer wet years. This is perhaps not surprising given that climate in the Kalahari is drier than that in adjacent parts of southern Africa. However, the extent to which the lower frequency of periods of above-normal rainfall is a true reflection of climate patterns or a product of data availability requires further investigation. As noted above, wet phases affected various parts of the study area in 1816-17, 1829-30, 1851-52, 1863-64, 1874-75, 1889-91 and 1899-1900. All but the first of these coincide directly with wetter conditions reported for other parts of southern Africa; the 1816-17 wet period that affected the Kuruman area occurred prior to the beginning of the Cape Province record. The heavy rainfall reported for the Kuruman-Molopo area, which began in the winter of 1829 and continued into 1830, coincides with the start of a wet phase that affected much of Cape Province but does not appear to have been as prolonged. Likewise, the above-normal rainfall recorded across much of the Kalahari in 1851-52 only coincides with the onset of more widespread wet conditions in other parts of the sub-continent. Heavy rainfall in the Kuruman and Lekatlong areas in 1863-64, however, appears to be symptomatic of wet conditions experienced in the eastern Cape. The most widespread wet conditions that affected almost all of the southern African subcontinent occurred in 1874-75 and 1889-91, with severe storms and floods affecting areas as far north as Palapye and south into much of the eastern Cape.

There are, however, some discrepancies between the records. For example, the drought that affected the eastern Cape in the early 1840s does not seem to have been particularly severe in the Kalahari region. Likewise, the dry conditions that existed across large areas of South Africa during the summer of 1872-73 are not apparent for much of the study area beyond Kuruman. Differences also exist for some of the wetter periods identified in southerly regions of the subcontinent when compared with data from the Kalahari. The 1823 wet period in the eastern Cape, for instance, is reflected in relatively high flows in the spring-fed Molopo river in the following year, but does not appear to have been more widespread in the Kalahari. Similarly, the 1844-45 and 1847-48 wet periods that affected much of Cape Province are manifest in above-average rainfall levels in the Kuruman area in 1844 but not elsewhere. The wetter spell between 1867 and 1872 in the eastern Cape also does not appear to have been particularly prevalent in the Kalahari, except for isolated reports of wetter conditions in the Lekatlong, Kuruman and Molopo areas during this period.

Interestingly, despite the similarities between the climate record compiled for this study and that of Lindesay and Vogel (1990), neither appear to show any clear evidence for rainfall cyclicity such as that identified from 20th century rainfall patterns by Tyson (1987) and Mason and Jury (1997). However, whether this suggests a lack of a cyclical relationship or is merely a product of the relatively coarse data resolution derived from historical evidence requires further investigation. 


\subsection{Possible causes of climate variability and their relationship to El Niño-SO (ENSO) events}

As noted in Section 2, the annual distribution of rainfall in southern Africa is strongly determined by the position of anticyclonic weather systems relative to the subcontinent (Tyson, 1987). There is also considerable evidence to suggest that rainfall variability is modulated by inter-hemispheric teleconnections arising from global atmospheric phenomena such as the SO (e.g. Nicholson and Entekhabi, 1986; Ropelewski and Halpert, 1987, 1989; Lindesay, 1988; Nicholson and Kim, 1997; Mason, 2001; Nicholson et al., 2001). This is primarily due to the influence of ENSO events upon sea-surface temperatures in the Indian and Atlantic oceans in immediate proximity to the African continent (Rocha and Simmonds, 1997a,b). In general, periods of low summer rainfall or drought appear to coincide broadly with low-phase SO events. More detailed analyses (e.g. Ropelewski and Halpert, 1987; Nicholson and Kim, 1997; Nicholson et al., 2001) indicate that drier than normal conditions occur during the summer immediately following a low-phase event, with greatest rainfall deficit usually occurring during the January-March quarter. It should be stressed, however, that whilst ENSO events appear to have an important impact upon southern African rainfall patterns, they are not the only cause of drought in southern Africa. Furthermore, not all droughts are associated with ENSO events. For example, the record-breaking ENSO event of 1997-98 did not result in the anticipated drought across southern Africa because dynamics in the Indian Ocean modulated the impact of the event (Landman and Mason, 1999; Mason, 2001).

Investigations of the link between rainfall levels and ENSO events suggest that the general association between ENSO and drought in southern Africa may have been relatively stable over the past two centuries, although not all ENSO events are necessarily followed by, or associated with, dry summers. For example, in an analysis of the coincidence of ENSO events and drought years in Botswana between 1946 and 1992, the majority of ENSO years were found to be associated with droughts apart from the events of 1953, 1957 and 1976 (Nicholson et al., 2001). Similarly, Lindesay and Vogel (1990) have analysed the historical relationship between ENSO events and drought in South Africa, based upon the previously discussed chronology for the summer rainfall zone of the southern and eastern Cape (Vogel, 1988a,b, 1989). This reveals that of the 20 periods of moderate to severe drought identified in South Africa between 1820 and 1900, 11 were broadly coincident with moderate or strong ENSO events (as identified by Quinn and co-workers (Quinn et al., 1978; Quinn et al., 1987; Quinn and Neal, 1992)), whilst a further six coincided with weaker events. In particular, the lengthy drought period of 1826-30 coincided with the very strong ENSO event in 1828, whilst severe droughts in 1864-65 and 1877-78 coincided with strong and very strong events respectively.

Patterns of drought in the Kalahari during the 19th century show an even closer coincidence with the distribution of ENSO events (Tables VII and VIII), with all drought episodes identified from documentary sources being associated with ENSO events of moderate strength or greater. Whether this provides evidence that the relationship between ENSO events and drought in the Kalahari was maintained throughout the 19th century, however, requires further investigation. The dry phases identified in this study span a total of 46 years of the 19th century. Given that 26 ENSO events of moderate strength or greater (encompassing a

Table VII. The occurrence of ENSO events of varying relative strength between 1815 and 1900 (after Quinn and Neal (1992))

\begin{tabular}{ll}
\hline Strength of ENSO event & Year \\
\hline $\mathrm{M}-$ & 1862 \\
$\mathrm{M}-\mathrm{M}+$ & $1887-89$ \\
$\mathrm{M}$ & $1821,1850,1852,1854,1857-58,1860,1874,1880$ \\
$\mathrm{M}+$ & $1817,1819,1824,1832,1837,1866,1867-68,1897$ \\
$\mathrm{M} / \mathrm{S}+$ & $1844-46$ \\
$\mathrm{~S}$ & $1864,1899-1900$ \\
$\mathrm{~S}+$ & 1871,1884 \\
$\mathrm{VS}$ & $1828,1877-78,1891$ \\
\hline
\end{tabular}

${ }^{a}$ Mindicates moderate strength, S indicates strong and VS very strong ENSO event. 
Table VIII. Drought years identified for the Kalahari (this study) together with years identified as ENSO events in the literature (Quinn and Neal, 1992)

\begin{tabular}{lcl}
\hline Drought years & Most intense dry phases & ENSO years (with relative strength) \\
\hline $1820-27$ & $1826-27$ & $1819, \mathrm{M}+; 1821, \mathrm{M} ; 1824, \mathrm{M}+$ \\
$1831-35$ & $1832-35$ & $1832, \mathrm{M}+$ \\
$1844-51$ & $1848-51$ & $1844-46, \mathrm{M} / \mathrm{S}+; 1850, \mathrm{M}$ \\
$1857-65$ & $1858-60$ & $1857-58, \mathrm{M} ; 1860, \mathrm{M}$ \\
& $1861-63$ & $1862, \mathrm{M}-$ \\
& $1865-66$ & $1866, \mathrm{M}+$ \\
$1877-86$ & $1877-81$ & $1877-78, \mathrm{VS} ; 1880, \mathrm{M}$ \\
& $1884-86$ & $1884, \mathrm{~S}+$ \\
$1894-99$ & $1895-97$ & $1897, \mathrm{M}+$ \\
\hline
\end{tabular}

${ }^{a}$ Mindicates moderate strength and S indicates strong ENSO event.

total of 33 years) have been identified by Quinn and Neal (1992) for the same time period, it is perhaps not surprising that there is a strong overlap between the data sets. More importantly, however, if such a strong relationship between ENSO and southern African rainfall does exist, then the lack of dry conditions in the centre of the subcontinent following, for example, the very strong ENSO events of 1828 and 1891, requires further explanation. Far from coinciding with a drought, as in more southerly parts of the southern African summer rainfall zone, the 1828 ENSO event occurred in the same year as wetter than average conditions in the Kuruman-Molopo area. Likewise, the 1891 event coincides with one of the most widespread wet phases to affect southern Africa during the 19th century. This may suggest that, despite being relatively strong ENSO events, the 1828 and 1891 episodes were associated with a weaker atmospheric response and weaker atmosphere-ocean coupling than other less severe events (Nicholson et al., 2001). It is possible that conditions in the Indian Ocean during these years were broadly analogous to those that occurred following the 1997-98 ENSO event, which also failed to result in a southern African drought (Landman and Mason, 1999; Mason, 2001). As such, whilst inter-hemispheric teleconnections associated with the SO may, in general, have a major impact upon central southern African climate, the precise nature of this relationship (at least as manifest in patterns of dry and wet phases during the 19th century) may be relatively complex. Further analysis of the documentary data compiled for this study is being undertaken; this will allow a more detailed picture of the timing, as well as of the relative magnitude, of seasonal rains in the Kalahari to emerge. This higher-resolution data will allow a better understanding of the relationship between ENSO events and patterns of annual rainfall to be developed, and should either support or refute the findings of Nicholson and co-workers (Nicholson and Kim, 1997; Nicholson et al., 2001) linking El Niño events to rainfall variability.

Finally, it may also be the case that regional rainfall patterns are influenced by other changes in atmospheric conditions in addition to those associated with ENSO, such as reductions in global radiation receipt. The wet period that affected the Kuruman area in 1816-17 coincided with a moderate-strength ENSO event in 1817, but also started in the year immediately following the eruption of Mount Tambora in Indonesia. The eruption of Tambora in 1815 is known to have had a major impact upon global stratospheric dust levels and resulted in 1816 being referred to in Europe and North America as 'the year without a summer' (Ballard, 1986: 360). It is possible that the disruption to weather patterns observed in the Northern Hemisphere in 1816 may also have been manifest as short-term climatic variability in southern Africa.

\section{CONCLUSIONS}

Unpublished letters, reports and journals written by missionaries working in mission stations across the Kalahari and surrounding areas of central southern Africa have been analysed to establish the sequence 
of climatic variability in the region during the 19th century. These sources have been supplemented by further published material written by various hunters and explorers (including missionaries such as David Livingstone) travelling throughout the Kalahari to identify climate patterns beyond the immediate areas of missionary activity. The key feature of the document-derived historical climatic chronology generated from these sources is the identification of six prolonged drought episodes and seven periods of aboveaverage rainfall which affected various parts of central southern Africa. Major droughts appear to have occurred in 1820-27, 1831-35, 1844-51,1857-65, 1877-86 and 1894-99, of which the drought phases of $1844-51,1857-65,1884-86$ and 1894-99 were the most widespread. Wetter periods are identified in 1816-17, 1829-30,1851-52, 1863-64, 1874-75, 1889-91 and 1899-1900, with the most widespread wet conditions occurring in 1889-91. The document-derived climate sequence for Barkly West has been compared with available rainfall records for the region (for the period 1883-1900). This comparison shows good agreement, suggesting that the climate chronology identified in this study is reasonably reliable.

The results of this study have been compared with historical climate chronologies for other parts of southern Africa, most notably those derived for the former Cape Province of South Africa by Vogel (1988a,b, 1989). This reveals that southern Africa appears to have been affected by widespread dry conditions that extended well beyond the Cape into various parts of the Kalahari in 1826-27, 1832-35, 1848-1851, 1858-60, $1861-63,1877-81,1884-86$ and 1894-99. Indeed, the dry phases of the early $1850 \mathrm{~s}, 1858-60,1861-63$ and 1894-99 may have extended well beyond the border of present-day Botswana into more northerly parts of the subcontinent. Wetter phases appear to have affected much of southern Africa in 1829-30, 1851-52, 1863-64, 1874-75, 1889-91 and 1899-1900, with the wet periods of 1874-75 and 1889-91 being associated with reports of flooding from Palapye in the north to parts of the eastern Cape in the south.

The precise nature of the causal mechanisms that generated these patterns of climatic variability are still unclear, but the periods of drought identified for the Kalahari during the 19th century appear to show a strong coincidence with the timing of moderate to strong ENSO events identified in the literature. Continuing analyses of the documentary data set used in this study may reveal further information about the nature of the timing and distribution of rainfall across the Kalahari during the 19th century. Nonetheless, this study confirms the usefulness of written materials as a proxy source of climatic information, even in relatively under-populated areas such as central southern Africa.

\section{ACKNOWLEDGEMENTS}

The research for this paper was undertaken as part of British Academy Research Grant APN 29960, for which the authors express their thanks. Quotations are reproduced with kind permission from the LMS/CWM archives. Thanks also go to Lesley Price, Rosemary Seton and other staff in the CWM archive at SOAS for their assistance in accessing material, to Chris Lewis of the School of Geography, University of Nottingham, for cartographic support, and to Emsie Klopper and Coleen de Villiers of the South African Weather Bureau for supplying rainfall data. Finally, thanks also to Coleen Vogel for invaluable electronic discussions, which have considerably improved the quality of this paper.

\section{NOTES}

1. Where information included within unpublished CWM archival materials is referred to in this paper, the original source is referenced as follows. Materials from the LMS collection are denoted by LMS followed by further letters indicating the material type. Items of correspondence from missionaries are denoted by the letter $\mathrm{C}$ followed by the box number, folder number and letter of jacket in which they are held in the archive. This is, in turn, followed by the name of the author, place of writing, and date (e.g. LMS C 9-4-B, Hamilton, Lattakoo, 15 December 1825). Reports written by individual missionaries are denoted by the letter R followed by the report box number, the author, place of production and date (e.g. LMS R Box 3, Price, Kuruman, 6 January 1898). Materials from special collections are referenced according to the initials of the author (e.g. DL for David Livingstone) and the archive box in which they are filed, together with an indication of location and date where appropriate (e.g. LMS DL Box 5, Kolobeng, November 1848). Other specialist materials, such as copies of David Livingstone's journals, are referred to by name. WMMS materials are all held on microfiche and are referred to as WMMS followed by the archive storage box number, microfiche number, administrative area of origin, date range of fiche, sub-box number, author, place of origin and date (e.g. WMMS South Africa Correspondence Fiche Box 27, Fiche 1067, Transvaal 1891, Box 330, Rogers, Mafikeng, 19 May 1898). 
2. Published documentary sources used in this study included Campbell (1822), Burchell (1824), Thompson (1827), Steedman (1835), Moffat (1842), Cornwallis-Harris (1852), Holden (1855), Andersson (1856, 1875), Livingstone (1857), Baines (1864), Leyland (1866), McKenzie (1883, 1887), Chapman (1886), Anderson (1888), Bryden (1893), Selous (1893), Hepburn (1895), Brown (1899), Kirby (1940), Wallis (1945), Schapera (1951), Livingstone and Schapera (1961), Burrow (1971) and Lye (1975).

\section{REFERENCES}

Anderson AA. 1888. Twenty-five Years in a Wagon. Chapman and Hall: London.

Andersson CJ. 1856. Lake Ngami; or, Explorations and Discoveries During Four Years' Wanderings in the Wilds of South Western Africa. Hurst and Blackett: London.

Andersson CJ. 1875. Notes of Travel in South Africa. Hurst and Blackett: London.

Baines T. 1864. Exploration in Southwest Africa. Longman, Greens and Co.: London.

Ballard C. 1986. Drought and economic distress in South Africa in the 1800s. Journal of Interdisciplinary History XVIII: 359-378.

Brown WH. 1899. On the South African Frontier. Sampson Low and Marston: London.

Bryden HA. 1893. Gun and Camera in Southern Africa. Edward Stanford: London.

Burchell WJ. 1824. Travels in the Interior of Southern Africa, Vols 1 and 2. Longman, Hurst, Rees, Orme, Brown and Green: London.

Burrow JA. 1971. Travels in the Wilds of Africa: Being the Diary of a Young Scientific Assistant who Accompanied Andrew Smith in the Expedition of 1834-36. A. A. Balkema: Cape Town.

Campbell Rev J. 1822. Travels in South Africa, Vols 1 and 2. Missionary Society London: London.

Chapman J. 1886. Travels in the Interior of South Africa, Vols 1 and 2. Bell and Daldy: London.

Cornwallis-Harris W. 1852. The Wild Sports of Southern Africa. Henry G. Bohn: London.

Currie RG. 1993. Luni-solar 18.6- and 10-11-year solar cycle signals in South African rainfall. International Journal of Climatology 13: $237-256$.

Endfield GH, Nash DJ. In press. Drought, desiccation and discourse: missionary correspondence and nineteenth century climate change in central southern Africa. Geographical Journal.

Endfield GH, O'Hara SL. 1997. Conflicts over water in "The Little Drought Age" in central Mexico. Environment and History 3: $255-272$.

Hepburn JD. 1895. Twenty Years in Khama's Country and Pioneering among the Batauana of Lake Ngami. Hodder and Stoughton: London.

Holden Rev WC. 1855. History of the Colony of Natal. Alexander Heylin: London.

Hurrell JW, van Loon H. 1994. A modulation of the atmospheric annual cycle in the Southern Hemisphere. Tellus A 46: $325-328$.

Kirkby PR (ed.). 1940. The Diary of Dr Andrew Smith, Director of the Expedition for Exploring Central Africa, 1834-1836, vol. 2. Van Riebeck Society: Cape Town.

Lamb HH. 1982. Climate, History and the Modern World. Methuen: London.

Landman WA, Mason SJ. 1999. Change in the association between Indian Ocean sea-surface temperatures and summer rainfall over South Africa and Namibia. International Journal of Climatology 19: 1477-1492.

Le Roy Ladurie E. 1972. Times of Feasts, Times of Famine - A History of Climates Since the Year 1000. George, Allen and Unwin: London.

Leyland J. 1866. Adventures in the Far Interior of South Africa. Routledge: London.

Lindesay JA. 1988. South African rainfall, the southern oscillation and a Southern Hemisphere semi-annual cycle. International Journal of Climatology 8: $17-130$.

Lindesay JA, Vogel CH. 1990. Historical evidence for southern oscillation - southern African rainfall relationships. International Journal of Climatology 10: 679-689.

Livingstone D. 1857. Missionary Travels and Researches in South Africa. John Murray: London.

Livingstone D, Schapera I. 1961. Missionary Correspondence 1841-1856. Chatto and Windus: London.

London Missionary Society. 1862. Report of the Directors to the Sixty-Eighth General Meeting of the Missionary Society, usually called the London Missionary Society, on Thursday, May 15th 1862, Reed and Pardon: London.

Lovett R. 1899. The History of the London Missionary Society, 1795-1895. Henry Frowde: London.

Lye WF (ed.). 1975. Andrew Smith's Journal of his Expedition into the Interior of South Africa, 1834-36. A. A. Balkema: Cape Town.

Mason SJ. 2001. El Nino, climate change, and southern African climate. Environmetrics 12: 327-345.

Mason SJ, Jury MR. 1997. Climatic variability and change over southern Africa: a reflection on underlying processes. Progress in Physical Geography 21: 23-50.

McCarthy TS, Cooper GRJ, Tyson PD, Ellery WN. 2000. Seasonal flooding in the Okavango Delta, Botswana - recent history and future prospects. South African Journal of Science 96: 25-33.

McKenzie J. 1883. Day-Dawn in Dark Places: A Story of Wanderings and Work in Bechwanaland. Cassell and Company: London.

McKenzie J. 1887. Austral Africa. 2 Vols. Sampson Low: London.

Metcalfe SE. 1987. Historical data and climatic change in Mexico - a review. Geographical Journal 153: $211-222$.

Moffat R. 1842. Missionary Labours and Scenes in Southern Africa. John Snow: London.

Morton B. 1994. Pre-Colonial Botswana: An Annotated Bibliography and Guide to the Sources. Botswana Society: Gaborone.

Nash DJ. 1996. On the dry valleys of the Kalahari: documentary evidence of environmental change in central southern Africa. Geographical Journal 162: 154-168.

Nicholson SE. 1978. Climatic variations in the Sahel and other African regions during the past five centuries. Journal of Arid Environments 1: 3-24.

Nicholson SE. 1979. The methodology of historical climatic reconstruction and its application to Africa. Journal of African History 20: $31-49$.

Nicholson SE. 1981. The historical climatology of Africa. In Climate and History, Wigley TML, Ingram MJ, Farmer G (eds). Cambridge University Press: Cambridge; 249-270. 
Nicholson SE. 2001. A semi-quantitative, regional precipitation data set for studying African climates of the nineteenth century, part 1 . Overview of the data set. Climatic Change 50: 317-353.

Nicholson SE, Entekhabi D. 1986. The quasi-periodic behaviour of rainfall variability in Africa and its relationship to the southern oscillation. Archfür Meteorologie, Geophysic and Bioklimatologie, Series A 34: 311-348.

Nicholson SE, Kim J. 1997. The relationship of the El Niño-southern oscillation to African rainfall. International Journal of Climatology 17: $117-135$.

Nicholson SE, Leposo D, Grist J. 2001. The relationship between El Niño and drought over Botswana. Journal of Climate 14: 323 -335.

O'Hara SL, Metcalfe SE. 1995. Reconstructing the climate of Mexico from historical records. The Holocene 5: 485-490.

Preston-Whyte RA, Tyson PD. 1988. The Atmosphere and Weather of Southern Africa. Oxford University Press: Cape Town.

Quinn WH, Neal VT. 1992. The historical record of El Niño events. In Climate Since AD 1500 (Revised Edition), Bradbury RS, Jones P (eds). Chapman and Hall: London; 623-648.

Quinn WH, Zopf DO, Short KO, Kuo Yang RTW. 1978. Historical trends and statistics of the southern oscillation, El Niño and Indonesian droughts. Fishery Bulletin 76: 663-678.

Quinn WH, Neal VT, De Mayolo SEA. 1987. El Niño occurrences over the past four and a half centuries. Journal of Geophysical Research 92(C13): 14449-14461.

Rocha A, Simmonds I. 1997a. Interannual variability of south-east African summer rainfall. Part I: relationships with air-sea interaction processes. International Journal of Climatology 17: 235-265.

Rocha A, Simmonds I. 1997b. Interannual variability of south-east African summer rainfall. Part II: Modelling the impact of sea-surface temperatures on rainfall and circulation. International Journal of Climatology 17: 267-290.

Ropelewski CF, Halpert MS. 1987. Global and regional scale precipitation patterns associated with the El Niño/southern oscillation. Monthly Weather Review 115: 1606-1626.

Ropelewski CF, Halpert MS. 1989. Precipitation patterns associated with the high phase of the southern oscillation. Journal of Climate 2: $268-284$.

Schapera I (ed.). 1951. Apprenticeship at Kuruman, Being the Journals and Letters of Robert and Mary Moffat 1820-1828. Chatto and Windus: London.

Selous FC. 1893. Travel and Adventure in South-East Africa. Rowland Ward: London.

Shaw PA. 1983. Fluctuations in the level of Lake Ngami: the historical evidence. Botswana Notes and Records 15: 79-84.

Shaw PA. 1984. An historical note of the outflows of the Okavango Delta system. Botswana Notes and Records 16: 127-130.

Shaw PA. 1985. The desiccation of Lake Ngami: an historical perspective. Geographical Journal 151: $318-326$.

Shaw PA. 1986. The palaeohydrology of the Okavango Delta: preliminary results. Palaeoecology of Africa 17: 51-58.

Shaw PA, Nash DJ. 1998. Botswana Society Bibliography of Botswana: the Geomorphology of Botswana. Botswana Society: Gaborone.

Steedman A. 1835. Wanderings and Adventures in the Interior of Southern Africa, 1 and 2. Vols Longman and Co.: London.

Swan SC. 1981. Mexico in the Little Ice-Age. Journal of Interdisciplinary History XIV: 633-648.

Thomas DSG, Shaw PA. 1991. The Kalahari Environment. Cambridge University Press: Cambridge.

Thompson G. 1827. Travels and Adventures in Southern Africa, vols 1 and 2. Henry Colburn: London.

Tyson PD. 1987. Climatic Change and Variability in Southern Africa. Oxford University Press: Cape Town.

Tyson PD, Dyer TGJ, Mametse MN. 1975. Secular changes in South African rainfall, 1880-1972. Quarterly Journal of the Royal Meteorological Society 101: 817-833.

Vogel CH. 1988a. Climatic change in the Cape Colony, 1820-1900. South African Journal of Science 84: 11.

Vogel CH. 1988b. 160 years of rainfall in the Cape - has there been a change? South African Journal of Science 84: 724-726.

Vogel CH. 1989. A documentary-derived climatic chronology for southern Africa, 1820-1900. Climatic Change 14: $291-306$.

Wallis JPR (ed.). 1945. The Matabele Journals of Robert Moffat 1829-1860 vol. 1. Chatto and Windus: London. 